\title{
Integrasi Pertanian Terhadap Perubahan Iklim di Wilayah Pedesaan, Pesisir dan Pulau-Pulau Kecil: Makalah
}

\author{
LAODE MUH. MUNADI \\ PASCASARJANA ILMU PERTANIAN UNIVERSITAS HALU OLEO \\ KENDARI SULAWESI TENGGARA \\ Email: lmmunadi@gmail.com
}

\section{BAB I \\ PENDAHULUAN \\ 1.1. Latar Belakang}

Pergantian iklim ialah suatu yang susah buat dihindari serta membagikan akibat terhadap bermacam segi kehidupan. Pertanian dikenal ialah zona yang sangat rentan terhadap pergantian iklim. Di Indonesia, akibat pergantian iklim mempunyai implikasi besar paling utama untuk ketahanan pangan nasional. Pergantian iklim global telah mempengaruhi fenomena kemiskinan serta jadi tantangan warga. Akibatnya antara lain menimbulkan punahnya bermacam tipe biologi serta kehancuran ekosistem. Kehancuran ekosistem yang diakibatkan oleh pergantian iklim hendak menimbulkan kerugian besar untuk warga yang hidupnya mengandalkan sumberdaya di sekitarnya.

Warga sudah memahami serta mempercayai terdapatnya pergantian hawa dengan penanda pergantian temperatur jadi lebih panas, masa kering (masa kemarau) serta masa hujan (masa hujan) yang tidak tertib, pergantian jumlah hujan (kuantitas) serta hari hujan yang tidak menentu ataupun susah diperkirakan semacam tadinya. Warga pula meningkatkan strategi menyesuaikan diri dengan pengembangan pola tanam, sistem tanam (budidaya kombinasi serta tumpang sari), mengubah tipe tumbuhan budidaya, metode budidaya serta usaha yang lain. Pengungkapan pengetahuan lokal tentang faktor hawa jadi dasar pengembangan strategi menyesuaikan diri serta mitigasi dalam pengelolaan sumberdaya alam biologi bagaikan salah satu upaya buat kurangi kemiskinan.

Terbentuknya pemanasan global diakibatkan oleh kenaikan konsentrasi gas rumah kaca (greenhouse gases) di atmosfir bumi yang ditimbulkan oleh pembakaran ataupun pemakaian bahan bakar fosil (minyak, gas, serta batu bara) oleh zona industri, transportasi, aktivitas alih guna lahan (land use change) serta aktivitas penggundulan hutan (deforestation). Tanpa upaya sistematis serta terintegrasi buat tingkatkan ketahanan terhadap transformasi cuaca serta revisi keadaan area lokal dan global, sehingga akibat yang ditimbulkan akibat variabilitas cuaca ke depan bakal terus menjadi besar, serta berdampak pada sulitnya meraih sistem pembangunan yang berkelanjutan. Oleh sebab itu, perlu dicoba transformasi yang mendasar dalam sistem perencanaan pembangunan. Permasalahan variabilitas cuaca wajib dijadikan sebagai salah satu variabel berarti dalam memutuskan dasar-dasar perencanaan pembangunan nasional baik jangka pendek, menengah maupun panjang.

Pengendalian perubahan cuaca dalam konteks pembangunan memerlukan manajemen variabilitas iklim secara efisien, serta pada saat bersamaan mengestimasi imbas perubahan iklim global jangka panjang secara komprehensif. Untuk dapat mengurangi dampak pergantian cuaca diperlukan pendekatan lintas sektoral baik pada tingkat nasional, regional, ataupun lokal. Strategi adaptasi lokal yang dikembangkan masyarakat lokal menjadi dasar pengembangan strategi adaptasi dan mitigasi terhadap perubahan iklim dalam rangka pengelolaan sumberdaya alam hayati yang lebih 
menguntungkan dan berkelanjutan. Pengembangan dan penerapan strategi adaptasi dan mitigasi yang tepat terhadap perubahan iklim memiliki pengaruh besar terhadap keberhasilan pengelolaan sumberdaya alam hayati, sehingga perubahan iklim yang terjadi tidak terlalu mempengaruhi kegiatan proses produksi dan hasil produksi.

Masyarakat pesisir merupakan salah satu kelompok masyarakat yang paling rentan menghadapi perubahan iklim. Perubahan kecil pada lingkungan mereka dapat memberikan dampak langsung pada kehidupan masyarakat pesisir khususnya pada sistem mata pencaharian. Nelayan misalnya, akan kesulitan untuk melaut dalam situasi cuaca yang tidak menentu. Situasi semacam ini juga dialami oleh berbagai mata pencaharian lain di wilayah pesisir, seperti penambak garam maupun ikan. Lebih lanjut, perubahan ekologis ini dapat berpengaruh pada kapasitas adaptif masyarakat pesisir. Untuk itu diperlukan konsep "Sistem Integrasi Pertanian Terhadap Perubahan Iklim di Wilayah Pedesaan, Pesisir dan Pulau-Pulau Kecil"

\section{BAB II \\ METODE PENGUMPULAN DATA}

Metode dalam penyusunan makalah berupa riset pustaka, yang berhubungan langsung dengan model pengelolaan pertanian dan dampak dari pengelolaan pertanian terhadap perubahan iklim pada wilayah pedesaan, pesisir dan pulau pulau kecil. Sehingga kajian dalam makalah ini menggunakan pendekatan riset pustaka, yakni dalam menyajikan dan memverifikasi serta menyimpulkan data, tidak menggunakan perhitungan. Semua literatur, dikumpulkan secara langsung yang relevan dengan kasus tersebut. Literatur yang telah diperoleh tersebut disusun sedemikian rupa sehingga mencerminkan coraknya sebagai sebuah kasus. Riset pustaka ini dimaksudkan untuk mengungkapkan berbagai teori-teori yang relevan dengan permasalahan yang sedang dikaji. Teknik ini dilakukan dengan cara membaca, mempelajari dan mengkaji literaturliteratur yang berhubungan dengan model pengelolaan pertanian dan dampak dari pengelolaan pertanian terhadap perubahan iklim pada wilayah pedesaan, pesisir dan pulau pulau kecil.

\section{BAB III \\ PEMBAHASAN MAKALAH}

\subsection{Model Pengelolaan Pertanian}

Bidang ekonomi pertanian memiliki kedudukan berarti dalam pembangunan, kemajuan serta kemakmuran bangsa. Pada masa reformasi paradigma pembangunan pertanian bukan meletakkan petani sekedar bagaikan partisipan dalam menggapai tujuan nasional namun bagaikan subyek buat menggapai tujuan nasional. Pengembangan kapasitas warga guna memesatkan upaya memberdayakan ekonomi petani, ialah inti dari upaya pembangunan pertanian/pedesaan. Upaya tersebut dicoba buat mempersiapkan warga pertanian jadi mandiri serta sanggup membetulkan kehidupannya sendiri. Kedudukan Pemerintah merupakan bagaikan stimulator serta fasilitator, sehingga aktivitas sosial ekonomi warga petani bisa berjalan dengan sebaikbaiknya.

\subsubsection{Model Umum Pengelolaan Pertanian (The Integrated Farming System)}

Sistem Pertanian terpadu merupakan sistem yang menggabungkan kegiatan pertanian, peternakan, perikanan, kehutanan dan ilmu lain yang terkait dengan pertanian dalam satu lahan, sehingga diharapkan dapat sebagai salah satu solusi bagi 
peningkatan produktivitas lahan, program pembangunan dan konservasi lingkungan, serta pengembangan desa secara terpadu. Diharapkan kebutuhan jangka pendek, menengah, dan panjang petani berupa pangan, sandang dan papan akan tercukupi dengan sistem pertanian ini.

Sistem ini membentuk suatu agroekositem yang masif. Agroekosistem dengan keanekaragamnnya tinggi seperti ini akan memberi jaminan keberhasilan usaha tani yang lebih tinggi (Fyka dkk., 2019). Keanekaragaman fungsional bisa dicapai dengan mengkombinasikan spesies tanaman dan hewan yang memiliki sifat saling melengkapi dan berhubungan dalam interaksi sinergetik dan positif, sehingga bukan hanya kestabilan yang dapat diperbaiki, namun juga produktivitas sistem pertanian dengan input yang lebih rendah (Lukas dkk., 2018). Kelebihan sistem ini, antara lain input dari luar minimal atau bahkan tidak diperlukan karena adanya daur limbah di antara organisme penyusunnya (Wulandari dkk., 2020). Biodiversitas meningkat apalagi dengan penggunaan sumberdaya lokal (Udawatta dkk., 2019). peningkatan fiksasi nitrogen (Jayasuriya \& Das, 2018). Resistensi tanaman terhadap jasad pengganggu lebih tinggi dan hasil samping bahan bakar biogas untuk rumah tangga (Zahara dkk., 2016; Setiawan dkk., 2019). Dikatakan pula bahwa SPT memiliki keuntungan baik aspek ekologi maupun ekonomi (Aziz dkk., 2014). Keuntungan yang dimaksud, yaitu lebih adaptif terhadap perubahan (habitat lebih stabil), ramah lingkungan, hemat energi (tidak ada energi yang terbuang), keanekaragaman hayati tinggi, lebih resisten, usaha lebih diversifikatif (risiko kegagalan relatif rendah), diversifikasi produk lebih tinggi, produk lebih sehat (minimalisasi residu senyawa berbahaya), keberlanjutan usaha tani lebih baik, serapan tenaga kerja lebih baik dan sinambung (Pramana dkk., 2012; Zahara dkk., 2016; Adhianto, 2019).

Siatem Pertanian Terpadu akan lebih handal apabila komponen penyusunnya merupakan sumberdaya lokal sehingga keberlanjutannya lebih terjamin (Hidayati dkk., 2020). Misal, komponen tanaman bersumber dari varietas lokal karena varietas ini lebih responsif terhadap lingkungan tumbuhnya sehingga tidak memerlukan masukan energi tinggi dari luar dan lebih tahan atau lebih mampu menyesuaikan terhadap perubahan lingkungan yang terjadi Baik secara fisik, kimia, hayati maupun ekonomi (Tarmizi, 2012; Hildawati dkk., 2018; Ningrum dkk., 2019). Selain itu untuk dapat memahami dampak negatif dan kerugian dari limbah yang tidak dikelola dengan baik dapat mengganggu kesehatan dan mencemari lingkungan sekitarnya sehingga adanya masalah limbah yang dihasilkan (Rust, 2013). Selain berasal dari penguraian sampah organik, metana muncul dari aktivitas manusia pada sektor pertanian (Baudron dkk., 2014; Zougmoré dkk., 2016). Terutama berasal dari ternak ruminansia (Ben Jebli \& Kahia, 2020). Sekaligus dihasilkan melalui proses metanogenesis dalam sistem pencernaan ternak (Lesinger dkk., 2020). Untuk itu salah satu metode pengelolaan yang baik adalah dengan menerapkan sistem pertanian terpadu (Baudron dkk., 2014). Atau diolah menjadi biogas dan pupuk organik (Kristjanson dkk., 2010).

\subsubsection{Model Pengembangan SPT pada Lahan Sawah}

Sebagaimana telah diuraikan di atas bahwa SPT merupakan sistem pertanian yang mampu mewujudkan pembangunan pertanian berkelanjutan dan diharapkan mampu menghambat laju alih fungsi lahan. Sistem pertanian terpadu dapat meningkatkan kemampuan para petani dalam memproduksi pupuk organik dan kemudian dapat membudayakan pertanian organik. Pertanian organik akan dapat menghasilkan produk pertanian dengan kualitas tinggi dan higienis yang tidak terkontaminasi dengan bahan kimia yang kurang baik bagi kesehatan. Sistem ini akan signifikan dampak positifnya 
dan memenuhi kriteria pembangunan pertanian berkelanjutan karena berbasis organik dan dikembangkan/diarahkan berbasis potensi lokal. Untuk itu salah satu upaya untuk mewujudkan sistem pertanian terpadu adalah pengembangan sistem pertanian terpadu (SPT) pada lahan sawah.

Sistem usahatani terpadu (integrated farming system), ialah suatu sistem usahatani yang didasarkan pada konsep daur-ulang biologis (biological recycling) antara usaha pertanaman, perikanan dan peternakan. Usahatani berbasis tanaman memberikan hasil samping berupa pakan bagi usahatani perikanan dan peternakan. Demikian pula sebaliknya, usaha perikanan dan peternakan memberikan hasil samping berupa pupuk bagi usahatani tanaman. Usaha perikanan menghasilkan pakan bagi peternakan, sedangkan usaha peternakan menghasilkan pupuk dan pakan untuk perikanan. Namun demikian maraknya penggunaan bahan kimia disinyalir telah menimbulkan kerusakan lingkungan, baik terhadap tanah, satwa, maupun fauna. Kelergantungan pada pupuk kimia yang muncul belakangan ini menunjukkan bahwa, tanaman yang diusahakan petani seakan-akan tidak mampu tumbuh dan berproduksi bila tidak diberi pupuk buatan (kimia).

Pemakaian bahan-bahan kimia berupa herbisida pada tanaman, telah menghilangkan keanekaragaman hewan-hewan tanah yang sangat pentjng bagi kelangsungan hidup tanaman (Kuivanen dkk., 2016). Sumber-sumber kehidupan masyarakat berupa spesies tanaman, khususnya tanaman liar untuk bahan kerajinan musnah (Rijal, 2019). Akhirnya, ribuan pekerja yang menggantungkan hidupnya dari sektor kerajinan menganyam harus menganggur karena bahan anyaman dari tanaman liar sudah lenyap (Parajuli dkk., 2018). Produktivitas tanah menjadi rendah (Stark dkk., 2016). Struktur tanah rusak (Yap dkk., 2019). Hal ini dapat dilihat dari keharusan petani menggunakan pupuk urea, khususnya urea tablet untuk tanaman padi (Howara, 2011). Biota sawah seperti cacing, belut, siput pun sebagai agen penyuburan tanah banyak berkurang atau bahkan sudah hilang (Yuliani, 2018). Kondisi kesuburan tanah semakin memprihatinkan ketika pola tanam yang sudah mengakar dalam usaha tani masyarakat tradisional terpaksa ditinggalkan (Mudaffar, 2020).

Sehingga sistem pertanian terpadu adalah suatu usaha tani yang memadukan berbagai praktek pertanian dengan tanaman maupun hewan dalam suatu sistem sedemikian rupa, sehingga ada kesinambungan antara produksi dan pemanfaatan sumberdaya alam (Iskandar \& Nurtilawati, 2019; Kurniati dkk., 2019; Ningrum dkk., 2019). Perpaduan antara berbagai komponen tersebut sangat diwarnai oleh unsur daur ulang limbah organik, dan sedikit atau sama sekali tidak menggunakan bahan kimia (Delima dkk., 2015; Jayasuriya \& Das, 2018; Khairad, 2020). Jadi ada kelanjutan yang tidak pernah putus dalam hal pemanfaatan materi organik yang dihasilkan dalam sistem usaha tani (Tumewu dkk., 2014). Dengan demikian, diterapkannya keseluruhan sislem biologis tersebut, akan ada penghematan biaya usaha tani dan sumber daya alam.

Sehingga dapat disimpulkan bahwa dampak dari praktek pembangunan pertanian yang selama selama ini terjadi, yaitu : (a) Peningkatan erosi permukaan tanah; (b) Penurunan kesuburan tanah; (c) Kehilangan bahan organik tanah; (d) Salinasi air tanah dan irigasi serta sedimentasi tanah; (e) Peningkatan pencemaran air dan tanah; (f) Eutrifikasi badan air; (g) Residu pestisida; (h) Pemerosotan keanekaragaman hayati pertanian; (i) Pemanasan global; (j) peningkatan pengangguran; (k) Penurunan lapangan kerja; (l) Peningkatan kemiskinan dan malnutrisi di perdesaan; (m) Ketergantungan petani pada pemerintah. 


\subsubsection{Model Pengembangan SPT pada Lahan Miring}

Masalah pertanian yang ada, hampir di seluruh dunia mencoba melaksakan metode sistem pertanian terpadu, yang pada pelaksanaannya berbeda-beda dalam pengintegrasian antara pertanian dan usaha lainnya, di antaranya ada yang melakasanakan pertanian dan perikanan, pertanian dan peternakan, perkebunan dan peternakan, pertanian dan usaha wisata, dan lainnya, dan pada intinya usaha tersebut memberikan hasil yang menguntungkan untuk kedua belah pihak. Sehingga upaya yang dapat dilakukan adalah dengan model pengembangan sistem pertanian terpadu (SPT) pada lahan miring.

Pada musim kering hijauan pakan ternak akan sangat terbatas, untuk mengatasi hal tersebut hijauan pakan ternak di musim kering perlu diterapkan sistem tiga strata (STS) (Nurcholis, 2011). Bertujuan agar pakan ternak tersebut dapat tersedia sepanjang tahun. Dewasa ini, masyarakat mulai memperhatikan masalah kerusakan lingkungan akibat kegiatan pertanian yang salah (Risal, 2018). Pada istilah pertanian yang berkelanjutan (Sustainable agriculture), keanekaragaman hayati (biodeversity), sistem pertanian terpadu (integrated agriculture system), dan pertanian berkelanjutan dengan kolaborasi teknologi rendah mulai dilirik dan dikembangkan di beberapa negara (Delima dkk., 2015; Guo dkk., 2016; Usman dkk., 2017; Hidayat dkk., 2020).

Ternak harus dikembangkan secara terpadu karena merupakan bagian dari pertanian organik (Howara, 2011). Melalui pengolahan tanah yang baik, dapat diketahui kebutuhan hara tanaman serta kondisi lingkungan dan ekologi dapat diperbaiki dan dilindungi tanpa harus tergantung pada pupuk kimia dan peptisida (Merakati dkk., 2017). Dengan demikian konsep sistem tiga strata (STS) dapat diuji dari sudut pandang keamanannya terhadap manusia, hewan, flora, dan fauna tanah. Meningkatkan keragaman semua kehidupan, tetapi tetap harmonis dengan alam, tanpa harus melakukan eksploitasi sumberdaya alam secara berlebihan (Hidayati dkk., 2020).

Lahan miring adalah suatu lahan terhadap hiding horizontal. Semakin besar sudut kemiringan lahan tertentu akan semakin besar kemungkinan erosi dan longsor. Kestabilan lahan pertanian daerah miring dan untuk mengurangi tingkat erosi tanah, maka diperlukan beberapa langkah diantaranya Pembuatan tanggul pasangan, Contour farming, Terasering, Contour strip cropping, Reboisasi, dan Crop rotation.

Pendekatan pada sistem tiga strata adalah keterpaduan antara sistem tiga strata dengan tanaman pangan atau tanaman industri dan ternak kedalam pola sistem tiga strata tersebut. Ketiga stratum (lapis) yang ada dalam unit sistem tiga strata, masingmasing punya peran atau fungsi tertentu. Stratum dua dan tiga berfungsi sebagai pagar hidup, sehingga ternak sukar mengganggu tanaman pangan atau industri di dalam unit sistem tiga strata, dan sebagai penahan angin kencang yang dapat merusak tanaman pangan.

Stratum satu berperan sebagai lahan penyedia makanan bagi ternak, sehingga menghalangi ternak merusak tanaman pangan kalau pagar ditembus oleh ternak. Pada lahan miring, stratum ini bisa menahan laju aliran air hujan sehingga kesuburan tanah dapat dipertahankan (bintil-bintil nitrogen pada akar legumenosa ikut menambah kesuburan tanah).

\subsubsection{Model Pengembangan SPT pada Lahan Rawan Erosi}

Pengembangan kawasan hutan yang mempunyai potensi erosi dapat dilakukan dengan pengembangan wanatani. Dalam sistem wanatani ini dapat dilakukan pemanfaatan lahan hutan untuk lumbung pangan berupa tanaman umbi-umbian. Petani dapat mengambil rumput atau hijauan dari tumbuhan lain untuk pakan ternak. Adapun 
untuk menghadapi musim kemarau dapat melakukan pemprosesan rumput dengan fermentasi, sehingga pakan dapat tersedia sepanjang waktu. Adapun kotoran ternak dapat diproses menjadi biogas dan pupuk organik.

Dalam menjalankan usaha tani, para petani cenderung belum memperhatikan usaha-usaha perlindungan lahan, sehingga ter-jadinya erosi tanah cukup tinggi. Erosi tanah yang cukup tinggi telah meningkatkan jumlah lahan kritis di negara kita (Nasir dkk., 2018). Luas daratan 192 juta hektar yang terdapat di wilayah nusantara, diantaranya 15,8 juta hektar merupakan lahan kering pertanian rakyat di luar kawasan hutan yang terdiri atas lahan tegalan dan pengembalaan. Untuk menjaga agar usaha tani yang dijalankan petani dapat berkelanjutan, maka perlu dilakukan langkah-langkah untuk merubah kegiatan usaha tani yang kurang memperhatikan kelestarian lingkungan menjadi kegiatan usaha tani yang mampu meningkatkan daya dukung lingkungan sehingga dapat mendukung kehidupan generasi sekarang dan mendatang. Pola pertanian yang mampu mendukung kehidupan sekarang dan mendatang adalah menerapkan sistem pertanian konservasi dalam kegiatan usahatani (Lal, 2001).

Lahan dengan kendala erosi perlu dihindari budidaya tanaman dengan hasil panen berupa umbi-umbian (Juanda, 2015). Ketela pohon yang dibudidayakan di lahan potensi erosi dapat meningkatkan laju erosi. Pengusikan tanah ini dapat merusak struktur tanah yang sudah mantap. Di samping itu, tanaman ketela mampu berproduksi di tanah yang miskin hara dan sifatnya rakus unsur hara sehingga dapat mempercepat pemiskinan tanah jika tidak disertai dengan pemberian bahan penyubur tanah, seperti pupuk organik. Untuk lahan yang rawan kekeringan dan atau banjir dapat dilakukan dengan konsep upland dan lowland. Prinsip penanganan kekeringan dan atau banjir pada prinsipnya dengan pengaturan air hujan sehingga tidak cepat turun ke lahan bawahan sebagai runoff. Usaha konservasi tanah dan air di kawasan atasan merupakan kunci dalam mengatasi kedua permasalahan, yaitu kekeringan dan atau banjir (Dainty dkk., 2016a). Di samping itu, dengan pembuatan bangunan yang dapat berfungsi dalam proses peresapan air di lahan atasan (upland). Hal ini dilakukan dengan meningkatkan resapan air di kawasan tangkapan air, sehingga air hujan tidak langsung turun ke lahan bawahan.

\subsubsection{Model Pengembangan SPT pada Lahan Konservasi}

Pertanian konservasi merupakan sistem pertanian yang mengintegrasikan teknik konservasi tanah dan air ke dalam sistem pertanian yang telah ada dengan tujuan untuk meningkatkan pendapatan petani, meningkatkan kesejahteraan petani dan sekaligus menekan erosi dan keseimbangan air dapat dipertahankan sehingga sistem pertanian tersebut dapat berlanjut secara terus menerus tanpa batas. Sistem usaha tani konservasi merupakan usaha tani khas lahan kering. Lahan kering dengan tingkat kemiringan yang tinggi sebagai tempat petani menjalankan usaha taninya, sehingga akan dapat diolah menjadi lahan yang produktif dan berkesinambungan.

Konsep pengembangan lahan marjinal pada lahan dengan tutupan yang rendah yaitu dengan menggunakan tanaman yang berfungsi sebagai tutupan lahan dan dapat bernilai ekonomi tanpa menebang pohon, atau tanaman hutan dengan hasil bukan kayu (Kremsa dkk., 2015). Pada konsep ini dapat dipadukan untuk pengembangan pertanian lainnya secara terpadu yaitu dengan memanfaatkan tanaman untuk makanan ternak (Moraine dkk., 2017). Pengolahan biogas dari kotoran ternak, pemanfaatan kotoran ternak untuk pupuk tanaman, dan pemanfaatan tanaman tinggi untuk konservasi air (Kremsa dkk., 2015). Konservasi adalah sebuah perwujudan cara pandang dan sikap tertentu terhadap alam, terhadap bumi dan tanah (Schiefer dkk., 2015). Konservasi 
yang benar dan juga kepedulian terhadap lingkungan pada umumnya adalah cara pandang dan sikap yang melihat bumi atau alam semesta sebagai subjek moral manusia tidak lagi dilihat sebagai pengusaha atau anggota yang lebih unggul dari makhluk hidup lain, melainkan salah satu anggota komunitas biotus yang saling tergantung dan terkait satu sama lain (Dumanski, 2015; (Auliyani, 2020).

Memang tidak mudah untuk mewujudkan usaha tani konservasi, mengingat banyaknya tantangan terutama ciri petani dan pertanian di daerah yang membutuhkan usaha tani konservasi antara lain petani pada umumnya miskin, petani berlahan sempit, petani tidak menganggap bahwa erosi di daerah pertanian adalah masalah pengelolaan pertanian, pengetahuan petani tentang teknik konservasi yang dapat meningkatkan produksi pertanian masih rendah, lahan pertanian umumnya tidak subur, harga hasil pertanian sangat rendah, dan kesempatan kerja di luar usaha pertanian sangat terbatas.

\subsection{Dampak Perubahan Iklim Terhadap Pengelolaan Pertanian}

Perubahan iklim merupakan hal yang tidak dapat dihindari akibat pemanasan global yang berdampak luas terhadap berbagai sendi kehidupan (Juanda, 2015). Perubahan pola curah hujan, peningkatan frekuensi kejadian iklim ekstrem, serta kenaikan suhu udara dan permukaan air laut merupakan dampak serius dari perubahan iklim yang berpengaruh terhadap sektor pertanian (Nuraisah \& Budi Kusumo, 2019). Untuk Indonesia ancaman akan perubahan iklim akan memberikan dampak yang serius terhadap pencapain target pembangunan berkelanjutan (Salampessy, 2018).

Perubahan iklim yang terjadi akibat emisi atau pelepasan gas rumah kaca semakin hari makin mengancam kehidupan umat manusia dan keanekaragaman hayati di muka bumi. Tanda-tanda fenomena ini semakin dirasakan, sebagaimana yang dialami Indonesia sebagai negara kepulauan, yang sangat rentan terhadap perubahan iklim karena telah menyebabkan berbagai bencana seperti banjir, longsor, kemarau panjang, angin kencang dan gelombang air laut tinggi (Mamenun \& Wati, 2020). Ancaman bencana bahkan dapat terjadi dalam intensitas yang lebih besar dan secara langsung dirasakan, misalnya pada masyarakat petani dan nelayan serta pada masyarakat yang tinggal di pesisir, pedesaan, maupun perkotaan (Putra \& Istianto, 2014). Dampak lebih luasnya tidak saja merusak lingkungan tetapi juga membahayakan kesehatan manusia, mengganggu ketersediaan bahan pangan, kegiatan pembangunan ekonomi, pengelolaan sumberdaya alam, dan infrastruktur (Nasprianto dkk., 2016). Hal ini akan dapat menjadi ancaman terhadap keberhasilan pencapaian pembangunan sosial ekonomi Indonesia (Hosang dkk., 2012; Yulianto, 2016).

Dampak perubahan iklim menjadi isu strategis karena persoalan ini dapat mengancam kepentingan nasional suatu negara. Keragaman dan perubahan iklim tersebut merupakan proses alami yang terjadi secara dinamis dan terus-menerus. Hal ini membawa pengaruh negatif terhadap lingkungan yang mengakibatkan dampak pergeseran pola curah hujan, besaran curah hujan, dan perubahan temperatur udara (Dainty dkk., 2016b). Dampak tersebut ditandai dengan mundurnya awal musim hujan dan makin panjangnya musim kemarau kemudian menyebabkan kekeringan (Prasasti \& Suciantini, 2013). Kekeringan merupakan salah satu bencana akibat iklim ekstrim yang paling sering terjadi di Indonesia dengan frekuensi dan tingkat risiko yang berbedabeda (Saputra dkk., 2020). Kekeringan dikategorikan sebagai fenomena bencana alam yang kompleks dan terjadi perlahan-lahan, tidak diketahui pasti awal dan kapan bencana ini berakhir serta mengakibatkan dampak kerugian yang besar khususnya pada sektor pertanian pangan dan sektor kehidupan lainnya seperti ekonomi, sosial, dan lingkungan (Dasanto dkk., 2014). 
Pada sektor pertanian, iklim merupakan satu faktor pembatas dalam proses pertumbuhan dan produksi tanaman dan menjadi sumberdaya yang sangat berharga dan memainkan peranan penting dalam pembangunan pertanian (Surmaini dkk., 2020). Jenis-jenis dan sifat-sifat iklim bisa menentukan jenis-jenis tanaman yang tumbuh pada daerah (Efendi dkk., 2012). Dampak perubahan iklim tidak hanya terkait dengan pemanasan suhu permukaan bumi, namun lebih penting terkait dengan dampaknya terhadap kerentanan pangan (Nuraini, 2015). Perubahan pola musim yang tidak teratur menjadikan para petani sulit mengatur perencanaan dan masa panen (Narulita, 2020).

Pada tingkat dunia, sektor pertanian menyumbang sekitar 14\% dari total emisi pada tahun 2000, sektor pertanian melepaskan emisi GRK ke atmosfer dalam jumlah yang cukup signifikan, yaitu berupa $\mathrm{CO} 2, \mathrm{CH} 4$, dan N20. $\mathrm{CO} 2$ sebagian besar dilepaskan dari proses pembusukan oleh mikroba, pembakaran serasah tanaman, dan dari bahan organik tanah (Baudron dkk., 2014). Sumber emisi tertinggi sektor pertanian berasal dari penggunaan pupuk, peternakan, lahan sawah, limbah ternak, dan pembakaran sisasisa pertanian (Thornton dkk., 2009). Emisi dari kegiatan produksi padi dan pembakaran biomassa sebagian besar merupakan kontribusi dari negara berkembang, yaitu masing-masing 97\% dan 92\%, di mana emisi metana ( $\mathrm{CH} 4)$ dari padi umumnya berasal dari Asia Selatan dan Asia Timur (82\%). Metana dihasilkan apabila dekomposisi bahan organik terjadi pada kondisi kekurangan oksigen, terutama pada proses fermentasi pencernaan ruminansia, kotoron ternak, dan lahan sawah. N20 dihasilkan dari transformasi mikroba pada tanah dan kotoran ternak dan meningkat apabila ketersediaan nitrogen melebihi kebutuhan tanaman, terutama pada kondisi basah.

Emisi sektor pertanian Indonesia pada tahun 2005 mencapai 141 juta ton karbon ekuivalen (Mt CO2e). Dibandingkan dengan negara lain seperti Amerika Serikat yang mencapai 442 Mt CO2e, China 1.171 Mt CO2e, Brasil 598 Mt CO2e, dan India $442 \mathrm{Mt}$ CO2e pada tahun yang sama, emisi dari sektor pertanian Indonesia termasuk kecil. Kontribusi emisi sektor pertanian jauh lebih rendah, yaitu 51,20 Mt CO2e atau hanya 8 $\%$ dari total emisi Indonesia (436,90 Mt CO2e), tidak termasuk emisi dari degradasi hutan, kebakaran gambut, dan dari drainase lahan gambut.

Perubahan iklim merupakan hal yang tidak dapat dihindari akibat pemanasan global dan akan berdampak luas terhadap berbagai aspek kehidupan, termasuk sektor pertanian (Bawayelaazaa Nyuor dkk., 2016). Indonesia akan mengalami peningkatan frekuensi kejadian iklim ekstrim seperti banjir dan kekeringan pada masa datang. Kondisi ini telah dirasakan oleh Indonesia berupa kejadian banjir dan kekeringan sehingga menyebabkan kerusakan tanaman padi sawah. Perubahan pola curah hujan dan kenaikan suhu udara menyebabkan produksi pertanian menurun secara signifikan. Kejadian iklim ekstrem berupa banjir dan kekeringan menyebabkan tanaman yang mengalami puso semakin luas. Peningkatan permukaan air laut menyebabkan penciutan lahan sawah di daerah pesisir dan kerusakan tanaman akibat salinitas. Dampak perubahan iklim yang demikian besar memerlukan upaya aktif untuk mengantisipasinya melalui strategi mitigasi dan adaptasi.

\subsection{Kesimpulan}

\section{BAB IV \\ KESIMPULAN DAN SARAN}

Dalam penulisan makalah ini dan berbagai studi pustaka terdapat 5 (lima) model pengelolaan pertanian dalam mengatasi perubahan iklim di wilayah Pedesaan, Pesisir dan Pulau-Pulau Kecil, sehingga Sistem Pertanian terpadu dapat menggabungkan kegiatan pertanian, peternakan, perikanan, kehutanan dan ilmu lain yang terkait 
dengan pertanian dalam satu lahan. Sehingga, diharapkan dapat sebagai salah satu solusi bagi peningkatan produktivitas lahan, program pembangunan dan konservasi lingkungan, serta pengembangan desa secara terpadu. Tetapi, Ancaman bencana bahkan dapat terjadi dalam intensitas yang lebih besar dan secara langsung dirasakan, misalnya pada masyarakat petani dan nelayan serta pada masyarakat yang tinggal di pesisir, pedesaan, maupun perkotaan. Sebab sekitar 14\% dari total emisi pada tahun 2000, Sektor pertanian melepaskan emisi GRK ke atmosfer dalam jumlah yang cukup signifikan, yaitu berupa $\mathrm{CO} 2, \mathrm{CH} 4$, dan N2O terutama pada proses fermentasi pencernaan ruminansia, kotoron ternak, dan lahan sawah.

\subsection{Saran}

Adapun saran yang dalam pengelolaan sistem ini pemerintah daerah, masyarakat, dan Stakholder bekerjasama dalam mengatasi perubahan iklim di wilayah Pedesaan, Pesisir dan Pulau-Pulau Kecil salah satunya adalah pelatihan pembuatan kompos dan biogas, sehingga efek pencemaran lingkungan terutama yang berasal dari kotoran ternak dapat teratasi demi keberlangsungan ekosistem esok dan yang akan datang.

\section{DAFTAR PUSTAKA}

Adhianto, K. (2019). Pemberian Limbah Singkong Terfermentasi Dan Mineral Mikro Organik Dalam Ransum Terhadap Ferforma Kambing. Sains Peternakan: Jurnal Penelitian Ilmu Peternakan, 17(2), 12-16. https://doi.org/10.20961/sainspet.v17i2.28834

Auliyani, D. (2020). Upaya Konservasi Tanah dan Air pada Daerah Pertanian Dataran Tinggi di Sub-Daerah Aliran Sungai Gandul. Jurnal Ilmu Pertanian Indonesia (JIPI), 25(3), 382-387. https://doi.org/DOI: 10.18343/jipi.25.3.381

Aziz, M., Muhtarudin, \& Widodo, Y. (2014). Potensi Limbah Jerami Padi Dan Daun Singkong Untuk Mendukung Program Pembibitan Sapi Po (Peranakan Ongole) Di Desa Sidomukti Kecamatan Tanjung Sari Kabupatn Lampung Selatan. Jurnal Ilmiah Peternakan Terpadu, 2(2), Article 2. https://doi.org/10.23960/jipt.v2i2.p\%p.

Baudron, F., Jaleta, M., Okitoi, O., \& Tegegn, A. (2014). Conservation agriculture in African mixed crop-livestock systems: Expanding the niche. Agriculture, Ecosystems \& Environment, 187, 171-182. https://doi.org/10.1016/j.agee.2013.08.020

Bawayelaazaa Nyuor, A., Donkor, E., Aidoo, R., Saaka Buah, S., Naab, J., Nutsugah, S., Bayala, J., \& Zougmoré, R. (2016). Economic Impacts of Climate Change on Cereal Production: Implications for Sustainable Agriculture in Northern Ghana. Sustainability, 8(8), 724. https://doi.org/10.3390/su8080724.

Ben Jebli, M., \& Kahia, M. (2020). The interdependence between CO2 emissions, economic growth, renewable and non-renewable energies, and service development: Evidence from 65 countries. Climatic Change, 162(2), 193-212. https://doi.org/10.1007/s10584020-02773-8.

Dainty, I., Abdullah, S. H., \& Priyati, A. (2016). Analisis Peluang Curah Hujan Untuk Penetapan Pola Dan Waktu Tanam Serta Pemilihan Jenis Komoditi Yang Sesuai Di Desa Masbagik Kecamatan Masbagik Kabupaten Lombok Timur. 1, 10.

Dasanto, B. D., Boer, R., Pramudya, B., \& Suharnoto, Y. (2014). Evaluasi Curah Hujan TRMM Menggunakan Pendekatan Koreksi Bias Statistik. Jurnal Tanah dan Iklim, 38 (1), 15-24. https://doi.org/10.21082/jti.v38n1.2014.15-24.

Delima, M., Karim, A., \& Yunus, M. (2015). Kajian Potensi Produksi Hijauan Pakan pada Lahan Eksisting dan Potensial untuk Meningkatkan Populasi Ternak Ruminansia di Kabupaten Aceh Besar. Jurnal Agripet, 15 (1), 33-40. https://doi.org/10.17969/agripet.v15i1.2297

Dumanski, J. (2015). Evolving concepts and opportunities in soil conservation. International Soil and Water Conservation Research, 3(1), 1-14. 
Efendi, M., Sunoko, H. R., \& Sulistya, W. (2012). Kajian Kerentanan Masyarakat Terhadap Perubahan Iklim Berbasis Daerah Aliran Sungai (Studi Kasus Sub Das Garang Hulu). Jurnal Ilmu Lingkungan, 10(1), 8-18. https://doi.org/10.14710/jil.10.1.8-18.

Fyka, S. A., Limi, M. A., Zani, M., \& Salamah, S. (2019). Analisis Potensi dan Kelayakan Usahatani Sistem Integrasi Padi Ternak (Studi Kasus di Desa Silea Jaya Kecamatan Buke Kabupaten Konawe Selatan). Jurnal Ilmu dan Teknologi Peternakan Tropis, 6(3), 375. https://doi.org/10.33772/jitro.v6i3.7520.

Guo, L., Wu, G., Li, Y., Li, C., Liu, W., Meng, J., Liu, H., Yu, X., \& Jiang, G. (2016). Effects of cattle manure compost combined with chemical fertilizer on topsoil organic matter, bulk density and earthworm activity in a wheat-maize rotation system in Eastern China. Soil and Tillage Research, 156, 140-147. https://doi.org/10.1016/j.still.2015.10.010.

Hidayat, H., Pagala, M. A., \& Zulkarnain, D. (2020). Basis Pengembangan Kawasan Sapi Potong Berdasarkan Luas Tanaman Perkebunan dan Tanaman Pangan di Kabupeten Muna. Jurnal Sosio Agribisnis, 5 (1), Article 1. https://doi.org/10.33772/jsa.v5i1.9916.

Hidayati, F., Yonariza, Y., Nofialdi, N., \& Yuzaria, D. (2020). Analisis Keuntungan dan Kendala Penerapan Konsep Sistem Pertanian Terpadu (SPT) di Indonesia. JIA (Jurnal Ilmiah Agribisnis): Jurnal Agribisnis dan Ilmu Sosial Ekonomi Pertanian, 5(3), 74-83. https://doi.org/10.37149/jia.v5i3.11688.

Hildawati, H., Iswandi, R. M., \& Suriana, S. (2018). Analisis Komoditas Basis dan Non Basis Sub Sektor Peternakan di Kecamatan Kusambi Kabupaten Muna Barat. JIA (Jurnal Ilmiah Agribisnis): Jurnal Agribisnis Dan Ilmu Sosial Ekonomi Pertanian, 3(1), 7-11. https://doi.org/10.33772/jia.v3i1.6736.

Hosang, P. R., Tatuh, J., \& Rogi, J. E. X. (2012). Analisis Dampak Perubahan Iklim Terhadap Produksi Beras Provinsi Sulawesi Utara Tahun 2013-2030. Eugenia, 18(3). https://doi.org/10.35791/eug.18.3.2012.4101.

Howara, D. (2011). Optimalisasi Pengembangan Usahatani Tanaman Padi Dan Ternak Sapi Secara Terpadu Di Kabupaten Majalengka. J. Agroland, 18(1), 43-43.

Iskandar, E., \& Nurtilawati, H. (2019). Persepsi Petani Dan Penerapan Teknologi Pengelolaan Tanaman Terpadu Di Desa Sukaresmi Kabupaten Bogor. Jurnal Agribisnis Terpadu, 12(2), 203-216. https://doi.org/10.33512/jat.v12i2.6781.

Juanda, B. R. (2015). Antisipasi Perubahan Iklim Melalui Pengelolaan Lingkungan Pertanaman Untuk Produksi Dan Ketahanan Pangan Berkelanjutan. 2, 10.

Khairad, F. (2020). Analisis Wilayah Sentra Produksi Komoditas Unggulan Pada Sub Sektor Tanaman Pangan Dan Tanaman Hortikultura Di Kabupaten Agam. Agrifo: Jurnal Agribisnis Universitas Malikussaleh, 5(1), 60-72. https://doi.org/10.29103/ag.v5i1.2958.

Kremsa, J., Křeček, J., \& Kubin, E. (2015). Comparing the impacts of mature spruce forests and grasslands on snow melt, water resource recharge, and run-off in the northern boreal environment. International Soil and Water Conservation Research, 3(1), 50-56. https://doi.org/10.1016/j.iswcr.2015.03.005.

Kristjanson, P., Waters-Bayer, A., Johnson, N., Tipilda, A., Njuki, J., Baltenweck, I., Grace, D., \& MacMillan, S. (2010). Livestock and Women's Livelihoods: A Review of the Recent Evidence. International Livestock Research Institute, 1-30.

Kuivanen, K. S., Alvarez, S., Michalscheck, M., Adjei-Nsiah, S., Descheemaeker, K., Mellon-Bedi, S., \& Groot, J. C. J. (2016). Characterising the diversity of smallholder farming systems and their constraints and opportunities for innovation: A case study from the Northern Region, Ghana. NJAS - Wageningen Journal of Life Sciences, 78, 153-166. https://doi.org/10.1016/j.njas.2016.04.003.

Kurniati, N., Efrita, E., \& Damaiyanti, D. (2019). Pendapatan Usahatani Sistem Integrasi Berbasis Padi dan Sapi di Kelurahan Rimbo Kedui Kabupaten Seluma Propinsi Bengkulu. Agrikan: Jurnal Agribisnis Perikanan, 12(1), 64-69.

Lal, R. (2001). Soil degradation by erosion. Land Degradation \& Development, 12(6), 519-539. https://doi.org/10.1002/ldr.472. 
Lesinger, K., Tian, D., Leisner, C. P., \& Sanz-Saez, A. (2020). Impact of climate change on storage conditions for major agricultural commodities across the contiguous United States. Climatic Change, 162(3), 1287-1305.

Lukas, A., Ngudiwaluyo, S., Mulyono, H., Rosyadi, I., Noor, I. M., \& Teng, P. N. L. (2018). Analisis Finansial Pemanfaatan Limbah Tandan Kosong Kelapa Sawit Menjadi Biokar Untuk Media Tanam. Jurnal Industri Hasil Perkebunan, 13(1), 37-42.

Mamenun, M., \& Wati, T. (2020). Analisis Karakteristik Kekeringan Lahan Padi Sawah di Wilayah Utara Provinsi Jawa Barat. Jurnal Tanah dan Iklim, 43(1), 43-57. https://doi.org/10.21082/jti.v43n1.2019.43-57.

Merakati, Siswanto, U., Adiprasetyo, T., Purnomo, B., \& Nuri, L. (2017). The Suitability of Different Sources Of Biofertilizers To Support Sustainability Of Organic Vegetables Practice In Bengkulu Province of Indonesia [Preprint]. INA-Rxiv. https://doi.org/10.31227/osf.io/gyjfv.

Moraine, M., Duru, M., \& Therond, O. (2017). A social-ecological framework for analyzing and designing integrated crop-livestock systems from farm to territory levels. Renewable Agriculture and Food Systems, 32(1), 43-56.

Mudaffar, R. A. (2020). Dampak Ekonomi Petani akibat Alih Fungsi Lahan Kakao menjadi Lahan Kelapa Sawit di Desa Karondang Kecamatan Tana Lili Kabupaten Luwu Utara. Perbal: Jurnal Pertanian Berkelanjutan, 8(2), 56-66.

Narulita, I. (2020). Pengaruh ENSO dan IOD pada Variabilitas Curah Hujan diDAS Cerucuk, pulau Belitung. Jurnal Tanah dan Iklim, 41(1), 45-60.

Nasir, B. H., Lakani, I., \& Monde, A. (2018). Penerapan Teknologi Usahatani Konservasi Terpadu Pada Daerah Rawan Longsor Untuk Pengembangan Pertanian Berkelanjutan Dan Peningkatan Pendapatan Masyarakat Di Kecamatan Gumbasa Kabupaten Sigi. Program Studi Agroteknologi, Fakultas Pertanian Universitas Tadulako, 2(1), 55-61.

Nasprianto, N., Mantiri, D. M. H., Kepel, T. L., Ati, R. N. A., \& Hutahaean, A. (2016). Distribusi Karbon Di Beberapa Perairan Sulawesi Utara (Carbon Distribution in North Sulawesi Waters). Jurnal Manusia dan Lingkungan, 23(1), 34. https://doi.org/10.22146/jml.18771

Ningrum, N. Z., Limi, M. A., \& Fyka, S. A. (2019). Analisis Multiplier Effect Pengembangan Sistem Mina Padi Bagi Masyarakat Lokal di Desa Epeesi Kecamatan Basala Kabupaten Konawe Selatan. JIA (Jurnal Ilmiah Agribisnis): Jurnal Agribisnis Dan Ilmu Sosial Ekonomi Pertanian, 4(6), 166-172. https://doi.org/10.33772/jia.v4i6.7928.

Nuraini, C. (2015). Kearifan Lingkungan Dalam Pengelolaan Hutan, Tanah Dan Sungai Di Desa Singengu, Kecamatan Kotanopan Kabupaten Mandailing Natal, Sumatera Utara (Environmental Wisdom on Management of Forest, Soil and River in Singengu Village, Kotanopan District). Jurnal Manusia dan Lingkungan, 22 (1), 100. https://doi.org/10.22146/jml.18730

Nuraisah, G., \& Budi Kusumo, R. A. (2019). Dampak Perubahan Iklim Terhadap Usahatani Padi Di Desa Wanguk Kecamatan Anjatan Kabupaten Indramayu. Mimbar Agribisnis: Jurnal Pemikiran Masyarakat Ilmiah Berwawasan Agribisnis, 5(1), 60. https://doi.org/10.25157/ma.v5i1.1639

Nurcholis, M. (2011). Pengembangan Integrated Farming System Untuk Pengendalian Alih Fungsi Lahan Pertanian. Prosiding Seminar Nasional Budidaya Pertanian, 2(2), 71-84.

P. Udawatta, R., Rankoth, L., \& Jose, S. (2019). Agroforestry and Biodiversity. Sustainability, 11(10), 2879. https://doi.org/10.3390/su11102879

P. W. Jayasuriya, H., \& Das, R. (2018). Agricultural resources management through a linear programming approach: A case study on productivity optimization of crop-livestock farming integration. Journal of Agricultural and Marine Sciences [JAMS], 22(1), 27. https://doi.org/10.24200/jams.vol22iss1pp27-35.

Parajuli, R., Dalgaard, T., \& Birkved, M. (2018). Can farmers mitigate environmental impacts through combined production of food, fuel and feed? A consequential life cycle assessment of integrated mixed crop-livestock system with a green biorefinery. Science of The Total Environment, 619-620, 127-143. 
Pramana, P., Widodo, Y., \& Liman. (2012). Potensi Pakan Hijauan di Bawah Naungan Pohon Karet Praproduksi dan Produksi di Perkebunan Masyarakat Desa Rukti Sedyo Kecamatan Raman Utara Lampung Timur. Jurnal Ilmiah Peternakan Terpadu, 1(1), Article 1. https://doi.org/10.23960/jipt.v1i1.p\%p.

Prasasti, I., \& Suciantini, S. (2013). Analisis Pemanfaatan Data CMORPH-IRI untuk Estimasi Curah Hujan Wilayah di Palangka Raya, Kalimantan Tengah dan Pekanbaru, Riau. Jurnal Tanah dan Iklim, 37(1), 1-8. https://doi.org/10.21082/jti.v37n1.2013.1-8.

Putra, I. setya, \& Istianto, H. (2014). Dampak Perubahan Muka Air Laut pada Daerah Rawa dengan Irigasi Pasang Surut: Pemodelan Daerah Rawa Tabunganen. Jurnal Tanah dan Iklim, 38(1), 43-49. https://doi.org/10.21082/jti.v38n1.2014.43-49.

Rijal, S. (2019). Agroforestry System: Approaches for Climate Change Mitigation and Adaptation. Acta Scientific Agriculture, 3(9), 140-142.

Risal, D. (2018). Sistem Pertanian Terpadu Hedgerow Meningkatkan Pendapatan Petani Lahan Kering. Jurnal Ecosolum, 7(1), 1. https://doi.org/10.20956/ecosolum.v7i1.5210.

Rust, J., \& Rust, T. (2013). Climate change and livestock production: A review with emphasis on Africa. South African Journal of Animal Science, 43(3), 255. https://doi.org/10.4314/sajas.v43i3.3

Salampessy, Y. L. A. (2018). Menakar Kapasitas Adaptasi Perubahan Iklim Petani Padi Sawah (Kasus Kabupaten Pasuruan Jawa Timur). Jurnal Ilmu Lingkungan, 16(1), 25. https://doi.org/10.14710/jil.16.1.25-34.

Saputra, R. A., Akhir, N., \& Yulianti, V. (2020). Efek Perubahan Zona Agroklimat Klasifikasi Oldeman 1910-1941 sampai dengan 1985-2015 terhadap Pola Tanam Padi Sumatera Barat. Jurnal Tanah dan Iklim, 42(2), 125-134.

Schiefer, J., Lair, G. J., \& Blum, W. E. H. (2015). Indicators for the definition of land quality as a basis for the sustainable intensification of agricultural production. International Soil and Water Conservation Research, 3(1), 42-49. https://doi.org/10.1016/j.iswcr.2015.03.003

Setiawan, B. D., Arfa'i, A., \& Nur, Y. S. (2019). Evaluasi Sistem Manajemen Usaha Pembibitan Sapi Bali Terintegrasi Dengan Perkebunan Kelapa Sawit Di Kabupaten Pasaman Barat, Provinsi Sumatera Barat. Jurnal Ilmiah Peternakan Terpadu, 7(3), 276-286. https://doi.org/10.23960/jipt.v7i3.p276-286.

Stark, F., Fanchone, A., Semjen, I., Moulin, C.-H., \& Archimède, H. (2016). Crop-livestock integration, from single practice to global functioning in the tropics: Case studies in Guadeloupe. European Journal of Agronomy, 80, 9-20.

Surmaini, E., Hadi, T. W., Subagyono, K., \& Syahputra, M. R. (2020). Integrasi Prediksi Musim dengan Model Simulasi Tanaman untuk Penentuan Waktu Tanam Padi. Jurnal Tanah dan Iklim, 42(2), 99-110. https://doi.org/10.21082/jti.v42n2.2018.99-110.

Tarmizi, H. B. (2012). Pengaruh Sistem Integrasi Padi Ternak (Sipt) Terhadap Peningkatan Pendapatan Petani Dan Dampaknya Terhadap Pengembangan Wilayah Di Kabupaten Serdang Bedagai. 15 (4), 10.

Thornton, P. K., van de Steeg, J., Notenbaert, A., \& Herrero, M. (2009). The impacts of climate change on livestock and livestock systems in developing countries: A review of what we know and what we need to know. Agricultural Systems, 101(3), 113-127. https://doi.org/10.1016/j.agsy.2009.05.002.

Tumewu, J. M., Panelewen, V. V. J., \& Mirah, A. D. P. (2014). Analisis Usaha Tani Terpadu Sapi Potong Dan Padi Sawah Kelompok Tani "Keong Mas" Kecamatan Sangkub, Kabupaten Bolaang Mongondow Utara (Studi Kasus). ZOOTEC, 34(2), 1. https://doi.org/10.35792/zot.34.2.2014.5521

Usman, U., Tirajoh, S., Baliadi, Y., \& Rauf, A. W. (2017). Kelayakan Usaha Tani Padi dan Sapi Potong Mendukung Pengembangan Sistem Integrasi Tanaman-Ternak di Kabupaten Merauke, Papua. Teknologi Peternakan dan Veteriner Mendukung Diversifikasi Sumber Protein Asal Ternak, 191-197. https://doi.org/10.14334/Pros.Semnas.TPV-2017-p.192198. 
Wulandari, S., Ardana, I. K., Massinai, R., \& Hartati, R. S. (2020). Accelerating the adoption of sustainable coffee-cattle integrated farming system. IOP Conference Series: Earth and Environmental Science, 418, 012011. https://doi.org/10.1088/17551315/418/1/012011

Yap, V. Y., Xaphokhame, P., de Neergaard, A., \& Bech Bruun, T. (2019). Barriers to AgroEcological Intensification of Smallholder Upland Farming Systems in Lao PDR. Agronomy, 9(7), 375. https://doi.org/10.3390/agronomy9070375.

Yuliani, D. (2018). Sistem Integrasi Padi Ternak Untuk Mewujudkan Kedaulatan Pangan. Jurnal Agroteknologi, 4(2), 13.

Yulianto, K. (2016). Agroekologi: Model Pertanian Berkelanjutan Masa Depan. Jurnal Tambora, 1(3). https://doi.org/10.36761/jt.v1i3.142

Zahara, D. A., Liman, \& Muhtarudin. (2016). Kapasitas Peningkatan Populasi Ternak Ruminansia Berdasarkan Potensi Limbah Tanaman Pangan Sebagai Pakan Ternak Di Kabupaten Lampung Selatan. Jurnal Ilmiah Peternakan Terpadu, 4(3), Article 3. https://doi.org/10.23960/jipt.v4i3.p\%p

Zougmoré, R., Partey, S., Ouédraogo, M., Omitoyin, B., Thomas, T., Ayantunde, A., Ericksen, P., Said, M., \& Jalloh, A. (2016). Toward climate-smart agriculture in West Africa: A review of climate change impacts, adaptation strategies and policy developments for the livestock, fishery and crop production sectors. Agriculture \& Food Security, 5(1), 26. https://doi.org/10.1186/s40066-016-0075-3 